\title{
The origin of the frequency selectivity in VOR motor learning revealed by a realistic cerebellar spiking neuron network model
}

\author{
Keiichiro Inagaki ${ }^{2}$, Seiichi Kobayashi ${ }^{1}$, Yutaka Hirata ${ }^{1 *}$ \\ From Nineteenth Annual Computational Neuroscience Meeting: CNS*2010 \\ San Antonio, TX, USA. 24-30 July 2010
}

The vestibuloocular reflex (VOR) counter rotates the eyes in the orbit during head rotation to obtain stable vision. It has been a popular model system to investigate cerebellar motor learning. The gain of the VOR (eye velocity / head velocity) can be modified by giving visual stimuli in- or out-of-phase with vestibular stimuli to the subject [1]. It has been shown that VOR motor learning exhibits frequency selectivity. Namely, the greatest gain change occurs at the frequency used for training, and less changes at frequencies further from the training frequency $[2,3]$. Existence of multiple frequency channels to process different frequency bands has been proposed to explain this phenomenon, although corresponding neuronal circuitries have not been identified anatomically or physiologically. In support of the multiple frequency channels for the VOR, it has been demonstrated that VOR gains can be changed differentially at 2 different frequencies simultaneously (ex. gain decrease at $0.05 \mathrm{~Hz}$ and gain increase at $2.5 \mathrm{~Hz}$ ) in squirrel monkeys [4] and goldfish [5].

\section{Methods}

In the present study, we investigated the neural origin of the frequency selectivity in VOR motor learning by using a realistic mathematical model of the VOR in which cerebellar cortical neuronal circuitry is explicitly composed by spiking neuron models of granule, Golgi, basket/stellate, and Purkinje cells. The parallel fiberPurkinje cell synaptic plasticity (both LTD [6] and LTP [7]) induced by climbing fiber input is implemented in the model. The model was constructed by revising our previous model [8] to be more physiologically plausible.

\footnotetext{
* Correspondence: yutaka@isc.chubu.ac.jp

'Department of computer science, Chubu University, Kasugai, Aichi, 487-8501, Japan
}

\section{Conclusion}

When the model was trained at $0.5 \mathrm{~Hz}$, frequency selectivity similar to that observed in the behavioral experiment [3] emerged after both gain decrease and increase trainings. Analyses of the model properties before and after the VOR trainings revealed that the cerebellar circuitry formed band-pass filters in response to vestibular and/or efference copy of eye movement signals after the trainings. The results suggest that the apparent multiple frequency channels in the VOR neuronal pathway are implicitly composed in the cerebellar cortical neuronal circuitry as band-pass filters for vestibular and/or efference copy of eye movement signals that are formed by the cerebellar synaptic plasticity.

\section{Author details}

'Department of computer science, Chubu University, Kasugai, Aichi, 487-8501, Japan. ${ }^{2}$ Computational science research program, RIKEN, Wako, Saitama, 351-0198, Japan.

\section{Published: 20 July 2010}

\section{References}

1. Hirata $Y$, Highstein SM: Acute adaptation of the vestibuloocular reflex: Signal processing by floccular and ventral parafloccular Purkinje cells. J. Neurophysiol 2001, 85:2267-2288.

2. Lisberger SG, Miles FA, Optican LM: Frequency-selective adaptation: evidence for channels in the vestibulo-ocular reflex? J. Neurosci 1983, 3(6):1234-1244.

3. Raymond JL, Lisberger SG: Behavioral analysis of signals that guide learned changes in the amplitude and dynamics of the Vestibulo-Ocular Reflex. J. Neurosci 1996, 16(23):7791-7802.

4. Hirata Y, Lockard JM, Hlghstein SM: Capacity of vertical VOR adaptation in squirrel monkey. J Neurophysiol 2002, 88:3194-3207.

5. Yoshikawa A, Yoshida M, Hirata Y: Capacity of the horizontal vestibuloocular reflex motor learning in goldfish. Proc. 26th annu. intl' conf. of the IEEE EMBS 2004, 478-481.

6. Ito M: Cerebellar Long-Term Depression: Characterization, Signal Transduction, and Functional Roles. Physiol. Rev 2001, 81:1143-1195. 
7. Hirano T: Depression and potentiation of the synaptic transmission between a granule cell and a Purkinje cell in rat cerebellar culture. Neurosci. Lett. 1990, 119:141-144.

8. Inagaki K, Hirata Y, Blazquez PM, Highstein SM: Computer simulation of vestibuloocular reflex motor learning using a realistic cerebellar cortical neuronal network model. Neural Information Processing 2008, 4984:902-912.

doi:10.1186/1471-2202-11-S1-P107

Cite this article as: Inagaki et al.: The origin of the frequency selectivity in VOR motor learning revealed by a realistic cerebellar spiking neuron network model. BMC Neuroscience 2010 11(Suppl 1):P107.

Submit your next manuscript to BioMed Central and take full advantage of:

- Convenient online submission

- Thorough peer review

- No space constraints or color figure charges

- Immediate publication on acceptance

- Inclusion in PubMed, CAS, Scopus and Google Scholar

- Research which is freely available for redistribution

Submit your manuscript at www.biomedcentral.com/submit
C Biomed Central 